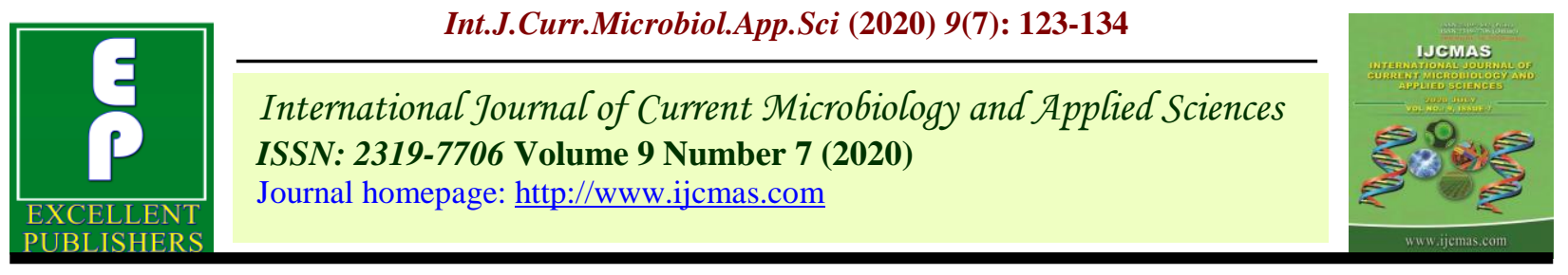

Original Research Article

https://doi.org/10.20546/ijcmas.2020.907.014

\title{
Development of Red Rice based Low Glycaemic Flour and the Microbial Activity during Storage
}

\author{
Krishna Mishra ${ }^{1 *}$ and Renu Mogra ${ }^{2}$ \\ Department of Food Science and Nutrition, MPUAT, Udaipur-313001, India \\ *Corresponding author
}

\begin{tabular}{|l|}
\hline Ke y w o r d s \\
Red rice, Low \\
glycaemic, \\
Pigmented rice, \\
Anthocyanin, \\
Diabetic friendly \\
\hline Article Info \\
\hline $\begin{array}{l}\text { Accepted: } \\
\text { 05 June } 2020 \\
\text { Available Online: } \\
\text { 10 July } 2020\end{array}$ \\
\hline
\end{tabular}

A B S T R A C T
Diabetic friendly rice, red rice (Oryza punctata) is a variety of pigmented rice that is red in colour because of its anthocyanin content. The present study was planned to develop a low glycaemic flour using red rice (Oryza punctata), its value added products and their quality evaluation. Red rice flour was the main ingredient taken for preparation of the low glycemic flour. The other flours taken for preparation were whole wheat flour (atta), bengal gram flour (besan), oats four and fenugreek powder (methi). The proportion of red rice and wheat flour were changed keeping the other ingredients constant and different treatments were tried for the selection of the most acceptable flour. Four proportions were taken, i.e. $\mathrm{T}_{1}, \mathrm{~T}_{2}, \mathrm{~T}_{3}$ and $\mathrm{T}_{4}$ which contained $20 \%, 30 \%, 40 \%$ and $50 \%$ of red rice flour respectively. Three traditionally consumed recipes like chapatti, cheela and dhokla were prepared from the four treatments. It was found the flour which contained $40 \%$ of red rice flour was more acceptable in terms of sensory parameters.

\section{Introduction}

The typical modern and high societal habits push individuals towards nutritional overload and a life-style very sedentary in origin. This disturbing reality is shown by the exponential rise in the prevalence of many metabolic disorders including type- 2 diabetes, which is estimated to reach the appalling rate of 300 million cases by 2030 (Anhe et al., 2013). Diabetes mellitus also called "madhumeham" has been known now for centuries as a disorder related to sweetness. Those persons with diabetes are detected with too much sugar both in blood and urine. However, there is nothing to worry as diabetes can now be kept under control by making certain changes in the food intake, life style, exercise and by the regular intake of the prescribed medicine (Raghuram et al., 2007). There are two major categories of diabetes, Type 1 diabetes, also called insulin dependent diabetes mellitus 
(IDDM), is usually diagnosed from the childhood, in which the body produces very little or no insulin and daily insulin injections are required and type 2 diabetes, also known as non-insulin dependent diabetes mellitus (NIDDM), is very common and almost about $90 \%$ of all the diabetic cases belong to this category and occurs usually in adulthood. In this type 2 diabetes diet, exercise and oral antidiabetic drugs can be sufficient for controlling the elevated blood sugar levels unless it is serious. Visanthamein and Savita (2001). If diabetes mellitus stays for longer duration then it is associated with an increase in the prevalence of various types of microvascular and macro-vascular diseases. Recent research studies have shown that the prevalence of the coronary heart diseases (CHD) in the diabetics in India may be as high as that in the migrant population. Hence, nutrition therapy is one of the major components for reducing the risk factor of chronic complications, especially the ones related to various macro vascular diseases (CHD \& CVD) Mohan et al., (2006). Therefore, Type 2 diabetes can be successfully treated by proper maintenance of diet before the onset of any secondary complications. Certain minor components of foods are now been recognized by almost every category of people for their healthpromoting characteristics, mainly for their different roles in prevention or alleviation of the effects of various chronic diseases such as cardiovascular disease, certain cancers and diabetes. These components include vitamin $\mathrm{C}$, vitamin $\mathrm{E}$, flavones, lignans, $\beta$-carotene, phenolic compounds and certain trace elements. Red rice is one of them. Diabetic friendly rice, red rice (Oryza punctata) is a variety of pigmented rice that is red in colour because of its anthocyanin content. It is generally consumed unhulled or partially hulled, containing a red outer husk, unlike the common brown rice. In comparison to polished rice, rice eaten with the germ intact has higher nutritional value. It comes with plenty of antioxidants, phytochemicals, phytonutrients, protein, Vitamin $\mathrm{E}$, iron and various other nutrients. The red coloured bran layer contains about $95 \%$ of minerals and dietary fiber of the whole rice which contains iron, potassium, zinc, manganese, sodium and so forth. Inner white layer contains predominantly proteins and carbohydrate (www.healthbenefits.com). As it is abundant in fibre and low glycaemic in nature it can be recommended in the diet of diabetic patients in moderate amount. It can not only supply nutrients but also fulfil the urge of eating rice of the diabetics. Nowadays people have been staying in a very busy world for which they are always in short of time. For this reason people tend to ignore various healthy food options and thus result in consuming quick ready to eat unhealthy and fast foods in a hurry. This leads to different types of health disorders. Hence, this research was planned to develop a red rice based low glycemic composite flour whose main ingredient was red rice along with other low glycemic ingredients such as bengal gram, oats, whole wheat flour, fenugreek powder in certain amount.

\section{Materials and Methods}

The present study has been planned to develop value added products using red rice (Oryza punctata) based low glycemic flour and the microbial activities during storage. Red rice flour was the main ingredient taken for preparation of the low glycemic flour. The other flours taken for preparation were whole wheat flour (atta), bengal gram flour (besan), oats four and fenugreek powder (methi). The proportion of red rice and wheat flour were changed keeping the other ingredients constant and different treatments were tried for the selection of the most acceptable flour. The four main flours including red rice flour (RRF), wheat flour (WF), bengal gram flour 
(BGF) and oats flour (OF) were taken in different proportions to make it $100 \mathrm{~g}$. About 0.2 gram of fenugreek powder (FP) was added to every treatment.

The flour standardization was done in terms of ingredients, amounts, processing steps and sensory qualities of products. To fulfill this purpose, the basic ingredients were replaced with red rice and other flours in different proportion to find out best combination for preparing each product.

All the treatments were evaluated by preparing different basic recipes so that the best flour could be selected. The recipes made from the flours were chapatti, pancake and dhokla.

\section{Microbial analysis:}

In the present investigation, the microbial load of the flour was calculated, i.e. the yeast and mould count at zero as well as monthly intervals of two months of storage period, as per the procedure described by the American Public Health Association (APHA, 1976).The method used for the preparation and composition of the media used for carrying out the experiment is as follows:-

Sterilization: Heat resistant glasswares like petriplates, conical flask, pipettes, test tubes were cleaned and sterilized in an oven and the temperature was maintained at $160^{\circ} \mathrm{Cfor}$ a period of about 2 hours (Vij and Subramaniam, 1999).

\section{Preparation of media}

Potato Dextrose Agar media was used for the yeast and mould count. The media was weighed, dissolved in the boiling distilled water, poured in the screw capped media bottles in the proportions of $100 \mathrm{ml}$ each and then autoclaved at $121^{\circ} \mathrm{C}$ for 15 minutes.
Preparation of dilution: One gram of the sample was added to about $9 \mathrm{ml}$ of sterilized saline solution inside a sterilized environment, i.e., U V Chamber and then mixed thoroughly for first dilution i.e., 1/10 of the concentration of the original sample. The subsequent dilutions were then obtained by transferring about $1 \mathrm{ml}$ of the previous dilutions to $9 \mathrm{ml}$ of the sterile saline in the cotton plugged test tubes.

Plating technique: One millilitre of dilution was transferred into already marked sterile petriplates in triplicates. They agar medium was melted (when solidified) over the hot water bath and $15 \mathrm{ml}$ of the media was poured to each petriplates. It was then mixed with the sample by rotation without spreading it over the edges of the pertidish. The mixture was then evenly spread over the bottom of the plate and the media was left to solidify.

Incubation and counting of colonies: The plates with the solidified medium and the samples were first inverted and then incubated in the incubator at the temperature $30 \pm 2^{\circ} \mathrm{C}$ and time $70-90 \pm 2$ hours. The developed colonies were counted and were expressed as colony forming units $(\mathrm{cfu} / \mathrm{g})$ of the sample.

\section{Results and Discussion}

Sensory parameters have always been analyzed to decide the acceptance of food by masses and have an edge over other equally important nutritional and safety aspects. Keeping this in view, when the sensory evaluation of four different low glycemic composite flours was carried out by taking different proportions of different flours as described in Table 3.1 the most acceptable one was selected for further study. The sensory evaluation of most common locally consumed recipes were done i.e. chapatti, cheela and dhokla and the sensory scores as given by the panel members for individual 
sensory parameters were statistically analyzed.

\section{Preparation of chapatti for finalization of} low glycemic flour

Results of the sensory evaluation of the chapatti (i.e., $\mathrm{T}_{1}, \mathrm{~T}_{2}, \mathrm{~T}_{3}$ and $\mathrm{T}_{4}$ ) prepared with 20, 30, 40 and 50 per cent addition of red rice flour respectively, 20 per cent addition of oats and bengal gram flour by changing the proportion of wheat flour accordingly have been presented in the Table 4.1 and Figure 4.1. As observed in Table 4.1, the mean sensory scores of chapatti ranged from 6.10 to 8.00 on 9-point hedonic scale.

The whole wheat flour composition was changed in different proportions and replaced by red rice, oats, bengal gram and fenugreek flours. Similarly, Singh and Pathak (2002) replaced the whole wheat flour that of rice, barley, millets, corn and black gram. In table 4.1 , the sensory scores of all the parameters of all the flours ranged from 6.1 to 8.0. The results showed that the flour based chapattis were found to fall under the category of 'liked very much' to 'liked moderately'. Similarly, Kadam et al., (2012) reported that the incorporation of soy flour in wheat flour at the proportion of 5 to 20 per cent for chapattis preparation showed the scores of different sensory attributes within the range of 6.0 to 8.6.

$\mathrm{T}_{3}$ was found to have the highest scores in all the parameters. This may be due to 40 per cent addition of red rice in which level the flour based chapatti was liked the most. But when it reached the 50 per cent level in $\mathrm{T}_{4}$, the dark colour and non-binding properties of red rice might have affected the sensory scores. Significant differences were found in between the scores of different flours. The scores of colour for $T_{1}, T_{2}$ and $T_{4}$ were low and not found significantly different.

\section{Preparation of cheela for finalization of low glycemic flour}

Results of the sensory evaluation of cheela (i.e., $\mathrm{T}_{1}, \mathrm{~T}_{2}, \mathrm{~T}_{3}$ and $\mathrm{T}_{4}$ ) for finalization of the best low glycaemic flour are described in Table 4.2 and Figure 4.2. As observed, the mean sensory scores of cheela ranged from 5.90 to 8.20 on 9-point hedonic scale. Kumar et al., (2004), incorporated amaranthus leaf powder with onion stalk in cheela at three levels: 5, 10 and 15 percent. It was observed cheela was liked the most with 5 percent incorporation of dried amaranthus leaf and onion stalk, however incorporation at 10 and 15 percent were also acceptable. According to Beniwal and Jood (2015), when bengal gram seed coat was incorporated by 5 per cent in dosa, it was rated as 'liked moderately'.

But according to this research, the result of the flour based cheelas came under the category of 'liked very much' to 'liked moderately'. This might have been due to addition of onion, green chillies and other spices like cumin seeds, red chilli powder, turmeric etc. And also the combination of red rice flour with oats, bengal gram and wheat flour led to an outer crispy layer with an inner soft layer in the cheela which was more acceptable. The highest sensory score was found in $\mathrm{T}_{3}$ in all the parameters which had 40 per cent of red rice flour. The reason might have been due to the more chunky and crispy properties of the cheela because of 40 per cent addition of red rice flour. It was found that increase in 10 per cent more of red rice flour, i.e. 50 per cent flour made the cheela hard and dark leading to decrease in sensory scores. In the study of Roopa et al., (2017) sensory attributes showed that the D2 (30\% rice+ $40 \%$ little millet+ $20 \%$ black gram $+10 \%$ lentil) formulated dosa was more acceptable in comparison to that of other formulated millet based dosa. In the present study, significant differences were found in 
between the scores of $T_{1}, T_{2}$ and $T_{4}$ except colour.

Preparation of dhokla for finalization of low glycemic flour

Table 4.3 and Figure 4.3 represent the results of the sensory evaluation of four types of dhoklas prepared from four types of flours (i.e., $\mathrm{T}_{1}, \mathrm{~T}_{2}, \mathrm{~T}_{3}$ and $\mathrm{T}_{4}$ ) for selection of the best low glycaemic flour Lohekar and Arya (2014) also developed value added instant dhokla mix with soybean, ragi and garedencress seeds. They performed four variations for sensory evaluation in comparison with basic variation. In the present study, as observed in the table, the mean sensory scores of dhokla ranged from 5.90 to 8.20 on 9-point hedonic scale. As a result, the flour based dhoklas came under the category of 'liked very much' to 'liked moderately'. The highest sensory score was found in $\mathrm{T}_{3}$ in all the parameters. The reason might have been the taste, porosity as well as mouth-feel of dhokla with 40 per cent red rice flour. Significant differences were found in between the scores of $T_{1}, T_{2}$ and $T_{4}$.

Kaur et al., (2016) developed dhokla with besan $(65 \mathrm{~g})$, potato flour $(20 \mathrm{~g})$, suji $(15 \mathrm{~g})$, salt $2.5 \mathrm{~g}$ and curd $(100 \mathrm{~g})$. It was accepted at 20 $50 \%$ level of incorporation of potato flour. Dhokla with addition of 20 per cent of potato flour obtained highest acceptability, i.e., 8.12. In the present research, dhokla prepared by incorporation of 50 per cent had decreased sensory attributes because it came out with hard texture and astringency.

Table.1 Proportions of different flours in various treatments

\begin{tabular}{|l|c|c|c|c|c|}
\hline S. No. & Types of flour & $\mathbf{T}_{\mathbf{1}}(\mathbf{g})$ & $\mathbf{T}_{\mathbf{2}}(\mathbf{g})$ & $\mathbf{T}_{\mathbf{3}}(\mathbf{g})$ & $\mathbf{T}_{\mathbf{4}}(\mathbf{g})$ \\
\hline $\mathbf{1}$ & Red rice flour & 20 & 30 & 40 & 50 \\
& & $(20 \%)$ & $(30 \%)$ & $(40 \%)$ & $(50 \%)$ \\
\hline $\mathbf{2}$ & Wheat flour & 40 & 30 & 20 & 10 \\
\hline $\mathbf{3}$ & Oats flour & 20 & 20 & 20 & 20 \\
\hline $\mathbf{4}$ & Bengal gram flour & 20 & 20 & 20 & 20 \\
\hline $\mathbf{5}$ & Fenugreek powder & 0.2 & 0.2 & 0.2 & 0.2 \\
\hline
\end{tabular}

Table.2 Acceptability scores of chapatti for finalization of low glycemic flour

\begin{tabular}{|l|c|c|c|c|c|c|c|}
\hline $\begin{array}{l}\text { S. } \\
\text { No. }\end{array}$ & Treatments & Colour & Flavour & Taste & Texture & Appearance & $\begin{array}{c}\text { Overall } \\
\text { acceptability }\end{array}$ \\
\hline $\mathbf{1}$ & $\mathrm{T}_{1}$ & $6.87^{\mathrm{b}} \pm 0.78$ & $6.20^{\mathrm{d}} \pm 0.41$ & $6.60^{\mathrm{b}} \pm 0.51$ & $6.40^{\mathrm{c}} \pm 0.52$ & $6.10^{\mathrm{d}} \pm 0.56$ & $6.10^{\mathrm{d}} \pm 0.56$ \\
\hline $\mathbf{2}$ & $\mathrm{T}_{2}$ & $6.60^{\mathrm{b}} \pm 0.69$ & $6.70^{\mathrm{b}} \pm 0.67$ & $6.50^{\mathrm{b}} \pm 0.71$ & $6.60^{\mathrm{b}} \pm 0.69$ & $6.70^{\mathrm{b}} \pm 0.82$ & $6.50^{\mathrm{b}} \pm 0.52$ \\
\hline $\mathbf{3}$ & $\mathrm{T}_{3}$ & $8.00^{\mathrm{a}} \pm 0.81$ & $7.90^{\mathrm{a}} \pm 0.73$ & $7.70^{\mathrm{a}} \pm 0.48$ & $7.70^{\mathrm{a}} \pm 0.48$ & $7.90^{\mathrm{a}} \pm 0.87$ & $7.50^{\mathrm{a}} \pm 0.52$ \\
\hline $\mathbf{4}$ & $\mathrm{T}_{4}$ & $6.70^{\mathrm{b}} \pm 0.82$ & $6.40^{\mathrm{c}} \pm 0.51$ & $6.30^{\mathrm{c}} \pm 0.48$ & $6.20^{\mathrm{d}} \pm 0.63$ & $6.40^{\mathrm{c}} \pm 0.69$ & $6.30^{\mathrm{c}} \pm 0.67$ \\
\hline & $\begin{array}{c}\text { Standard } \\
\text { error }\end{array}$ & 0.11 & 0.08 & 0.08 & 0.08 & 0.11 & 0.08 \\
\hline & CD 5\% & 0.22 & 0.17 & 0.16 & 0.17 & 0.22 & 0.16 \\
\hline
\end{tabular}


Table.3 Acceptability scores of cheela for finalization of low glycemic flour

\begin{tabular}{|l|c|c|c|c|c|c|c|}
\hline S.No. & Treatments & Colour & Flavour & Taste & Texture & Appearance & $\begin{array}{c}\text { Overall } \\
\text { acceptability }\end{array}$ \\
\hline $\mathbf{1}$ & $\mathrm{T}_{1}$ & $6.30^{\mathrm{b}} \pm 0.82$ & $6.60^{\mathrm{b}} \pm 0.51$ & $6.70^{\mathrm{b}} \pm 0.48$ & $6.60^{\mathrm{b}} \pm 0.51$ & $6.20^{\mathrm{c}} \pm 0.42$ & $6.30^{\mathrm{b}} \pm 0.48$ \\
\hline $\mathbf{2}$ & $\mathrm{T}_{2}$ & $6.30^{\mathrm{b}} \pm 0.48$ & $6.60^{\mathrm{b}} \pm 0.96$ & $6.50^{\mathrm{c}} \pm 0.84$ & $6.60^{\mathrm{b}} \pm 0.69$ & $6.60^{\mathrm{b}} \pm 0.84$ & $6.30^{\mathrm{b}} \pm 0.48$ \\
\hline $\mathbf{3}$ & $\mathrm{T}_{3}$ & $8.20^{\mathrm{a}} \pm 0.63$ & $8.10^{\mathrm{a}} \pm 0.56$ & $8.00^{\mathrm{a}} \pm 0.66$ & $8.00^{\mathrm{a}} \pm 0.47$ & $8.00^{\mathrm{a}} \pm 0.81$ & $7.70^{\mathrm{a}} \pm 0.48$ \\
\hline $\mathbf{4}$ & $\mathrm{T}_{4}$ & $6.40^{\mathrm{b}} \pm 0.69$ & $5.90^{\mathrm{c}} \pm 0.73$ & $6.20^{\mathrm{d}} \pm 0.63$ & $5.90^{\mathrm{c}} \pm 0.56$ & $6.20^{\mathrm{c}} \pm 0.78$ & $5.80^{\mathrm{c}} \pm 0.63$ \\
\hline & $\begin{array}{c}\text { Standard } \\
\text { error }\end{array}$ & 0.09 & 0.10 & 0.09 & 0.08 & 0.10 & 0.08 \\
\hline & CD 5\% & 0.19 & 0.21 & 0.19 & 0.16 & 0.21 & 0.15 \\
\hline
\end{tabular}

Table.4 Acceptability scores of dhokla for finalization of low glycemic flour

\begin{tabular}{|l|c|c|c|c|c|c|c|}
\hline S. No. & Treatments & Colour & Flavour & Taste & Texture & Appearance & $\begin{array}{c}\text { Overall } \\
\text { acceptability }\end{array}$ \\
\hline $\mathbf{1}$ & $\mathrm{T}_{1}$ & $6.30^{\mathrm{c}} \pm 0.67$ & $6.20^{\mathrm{c}} \pm 0.63$ & $6.20^{\mathrm{b}} \pm 0.63$ & $6.50^{\mathrm{b}} \pm 0.70$ & $6.30^{\mathrm{c}} \pm 0.48$ & $5.90^{\mathrm{c}} \pm 0.31$ \\
\hline $\mathbf{2}$ & $\mathrm{T}_{2}$ & $6.50^{\mathrm{b}} \pm 0.52$ & $6.40^{\mathrm{b}} \pm 0.84$ & $6.40^{\mathrm{b}} \pm 0.84$ & $6.30^{\mathrm{c}} \pm 0.67$ & $6.60^{\mathrm{b}} \pm 0.69$ & $6.00^{\mathrm{c}} \pm 0.67$ \\
\hline $\mathbf{3}$ & $\mathrm{T}_{3}$ & $8.10^{\mathrm{a}} \pm 0.74$ & $8.30^{\mathrm{a}} \pm 0.67$ & $8.00^{\mathrm{a}} \pm 0.47$ & $8.00^{\mathrm{a}} \pm 0.47$ & $8.20^{\mathrm{a}} \pm 0.63$ & $7.80^{\mathrm{a}} \pm 0.42$ \\
\hline $\mathbf{4}$ & $\mathrm{T}_{4}$ & $6.50^{\mathrm{b}} \pm 0.70$ & $6.50^{\mathrm{b}} \pm 0.97$ & $6.50^{\mathrm{b}} \pm 0.97$ & $6.20^{\mathrm{c}} \pm 0.63$ & $6.30^{\mathrm{c}} \pm 0.94$ & $6.20^{\mathrm{b}} \pm 0.63$ \\
\hline & $\begin{array}{c}\text { Standard } \\
\text { error }\end{array}$ & 0.09 & 0.10 & 0.10 & 0.09 & 0.10 & 0.07 \\
\hline & CD 5\% & 0.19 & 0.20 & 0.21 & 0.18 & 0.20 & 0.15 \\
\hline & & & & & & \\
\hline
\end{tabular}

Table.5 Microbial (yeast and mould) activities during storage

\begin{tabular}{|c|c|c|}
\hline S. No. & Days & Activity $(\mathbf{c f u} / \mathbf{g})$ \\
\hline $\mathbf{1}$ & 0 & Nil \\
\hline $\mathbf{2}$ & 30 & $2.33 \pm 0.57$ \\
\hline $\mathbf{3}$ & 60 & $3.5 \pm 0.5$ \\
\hline
\end{tabular}


Plate.1 Chapatti prepared for finalization of low glycaemic flour

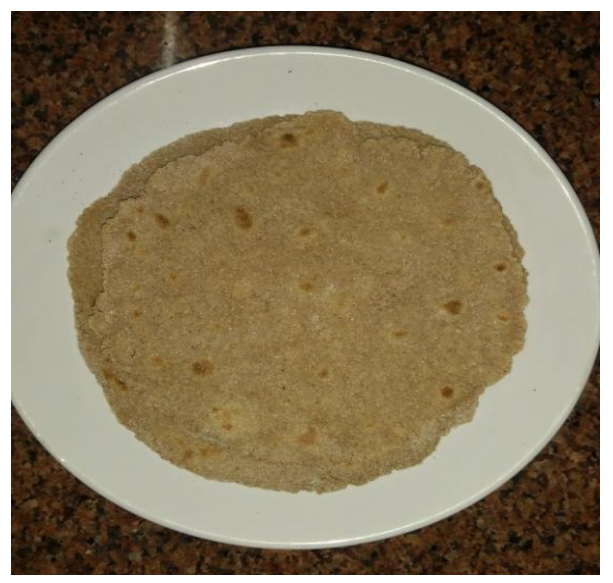

$\mathbf{T}_{1}$

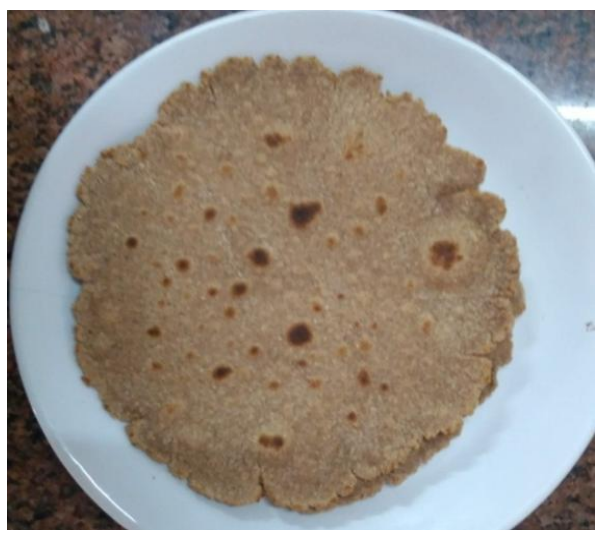

$\mathbf{T}_{3}$

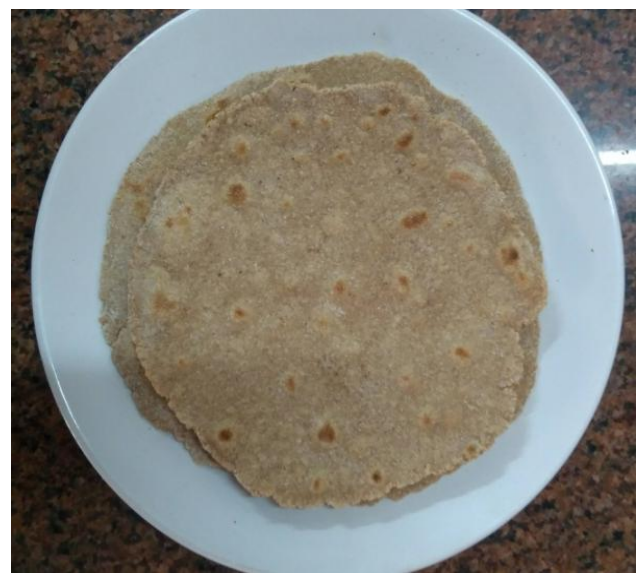

$\mathbf{T}_{2}$

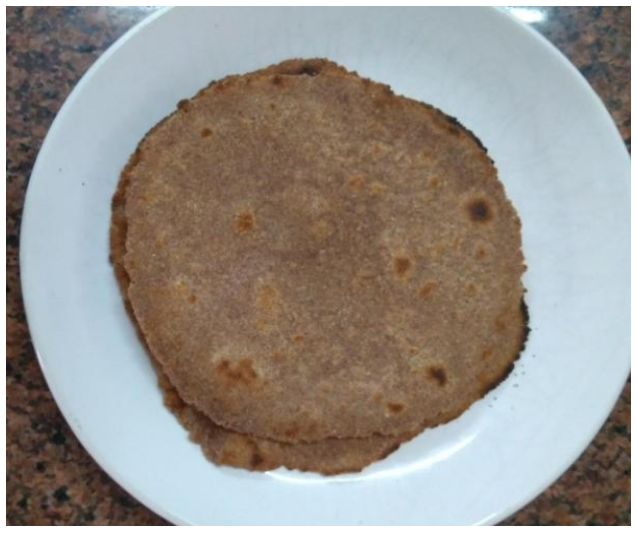

$\mathbf{T}_{4}$

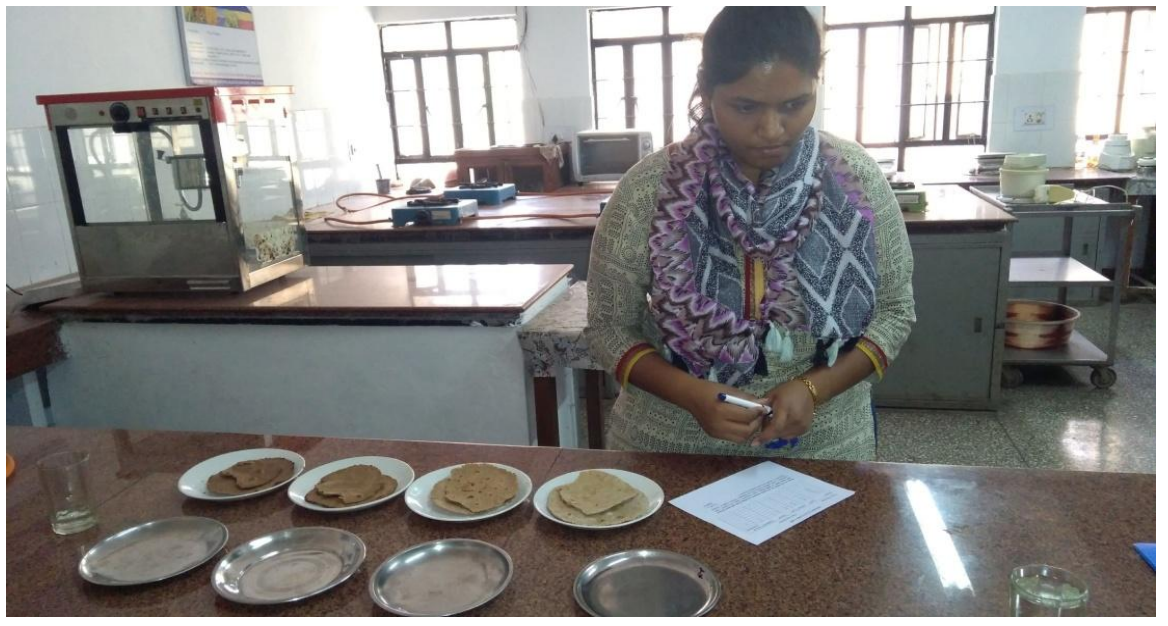


Plate.2 Cheela prepared for finalization of low glycaemic flour
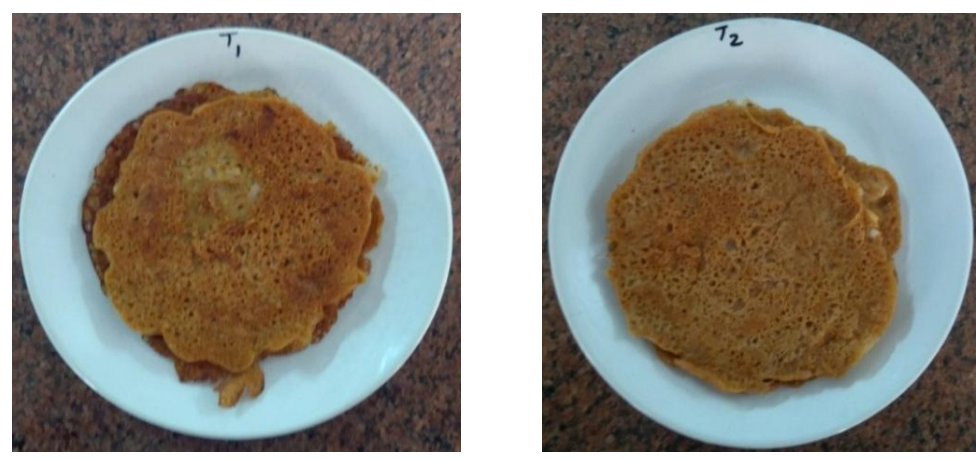

$T_{1}$

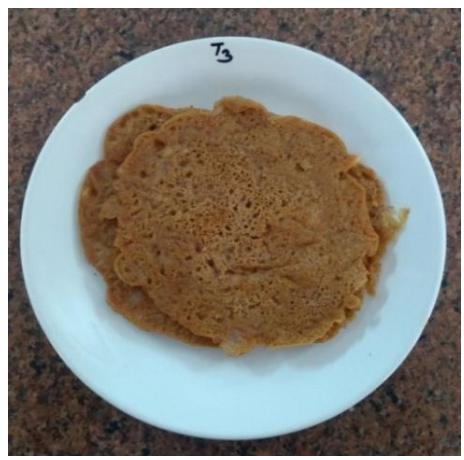

$\mathbf{T}_{3}$
$\mathbf{T}_{2}$

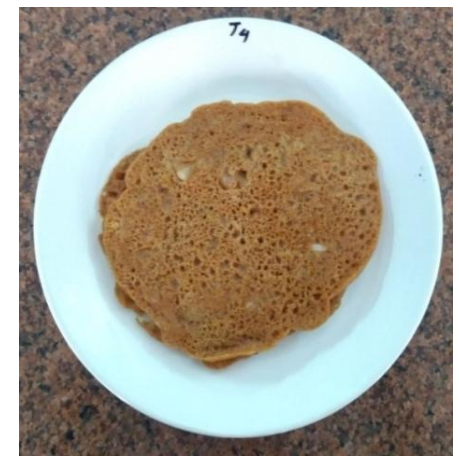

$\mathbf{T}_{4}$

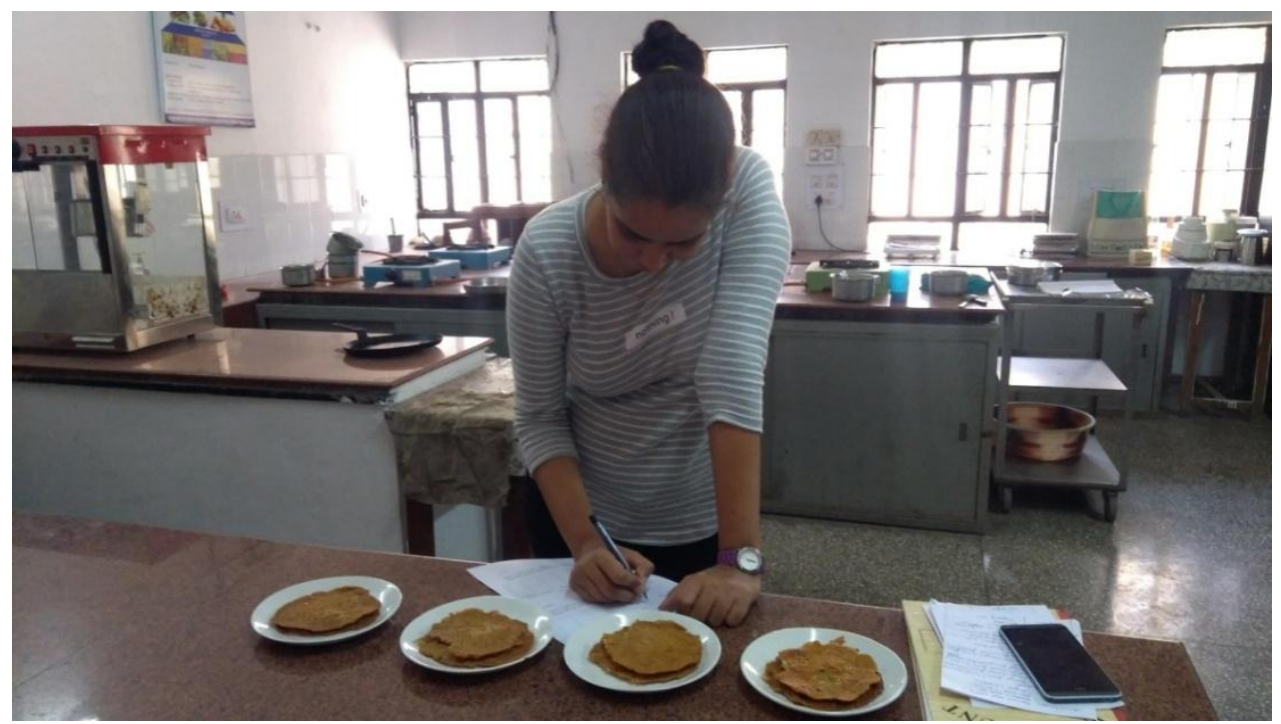


Plate.3 Dhokla prepared for finalization of low glycaemic flour
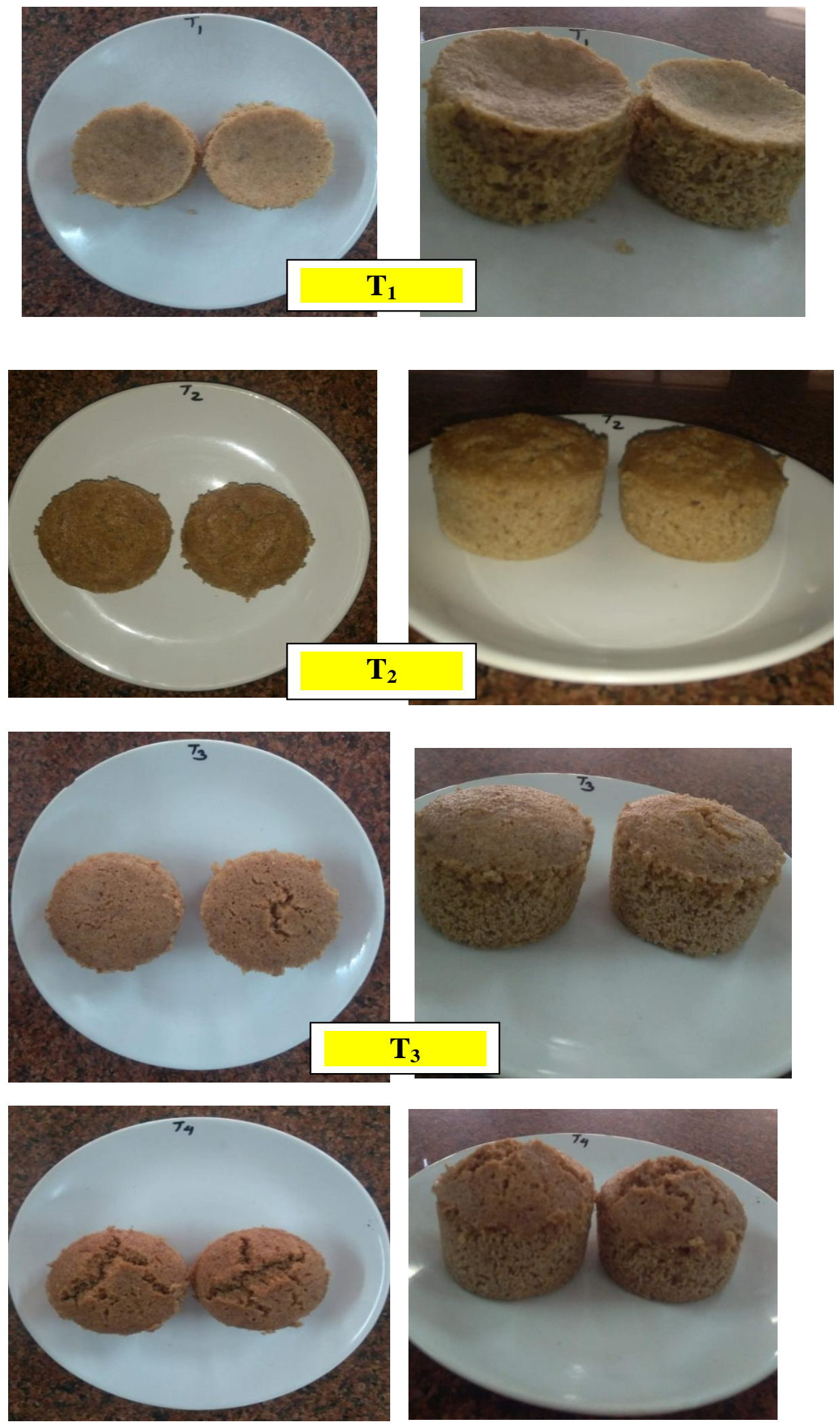
Plate.4 Red rice based low glycaemic flour selected for further studies

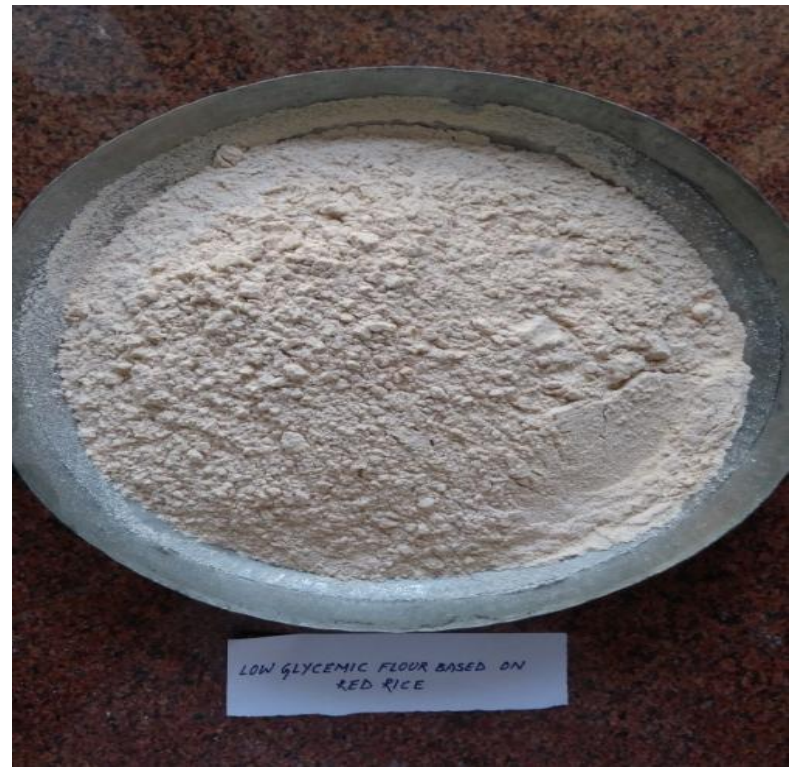

Patangare (2019) conducted the sensory evaluation of instant dhokla mix in which sample D2 containing 20 per cent foxtail millet and 20 per cent horse gram flour was more acceptable and scored 8.7 compared to D4(7.1) containing 30 per cent horse gram flour. But beyond 30 per cent level, the overall acceptability score decreased showing negative impact on sensory parameters.

After conducting the sensory evaluation of chapatti, cheela and dhokla prepared from different flours with varying proportions, the $\mathrm{T}_{3}$ flour, i.e. the flour containing $40 \%$ of red rice flour was selected for the further studies based on the acceptability scores.

Assessment of microbial activities of selected low glycaemic flour during storage

Microbial load is one of the important determinants which indicate the keeping quality of any type of food product. Contamination affects the cereal yield along with the quality as well as the nutritional value of a food product adversely. Mould growth is one of the most common causes of the microbial spoilage and also deterioration in the quality of any cereal grain or flour during the storage period (Victor et al., 2013).

The quality and also handling practices of the produce after post harvest of the cereals play a key role in maintaining the keeping quality of the flour Berghofer et al., (2003). Cereals may be contaminated with the mycotoxins which produce fungi and other pathogenic bacteria during the growth of crop, stages of pre and post harvesting, drying, transportation of the crop and its storage (Setamou et al., 1997).

Although the flours are generally considered as safe products because of their low water activity, still many of the pathogenic and nonpathogenic microbes contaminate them during their processing and storage (ICMSF, 1998; Berghofer et al., 2003).

The microorganisms that contaminate the flour survive for longer periods and produce various toxins, even after the retardation of their growth under low moisture conditions. 
The results of the microbial activities of the yeast and mould during the entire storage period after every 30 days gap for 2 months have been illustrated in Table 4.23. First the microbial activity in the ' 0 'th' day was observed where the microbial activity was found to be nil. Then the activity after 30 days was observed which was found to be $\log$ $2.33 \mathrm{cfu} / \mathrm{g}$ and after 60 days the value was $\log$ $3.5 \mathrm{cfu} / \mathrm{g}$.

Victor et al., (2013) also found that the yeast and moulds ranged from $\log 1.04 \pm 0.55 \mathrm{cfu} / \mathrm{g}$ in case of cake flour to $\log 3.90 \pm 0.76 \mathrm{cfu} / \mathrm{g}$ in the whole (brown) wheat flour during the whole storage period.

The study revealed that the flour incorporated with 40 per cent of red rice flour was the most acceptable in terms of all the sensory attributes of chapatti, cheela and dhokla. In the present research investigation, the results of the microbial examination of the red rice based low glycaemic flour revealed that it was safe for human consumption as the indicators of the microbial load were within range of the permissible limit. The reason behind this might have been low moisture and good hygienic conditions maintained throughout the study starting from product development to packaging and storage of the sample.

\section{Acknowledgement}

For this research study the author acknowledge the encouragement and guidance of the Advisory committee, facilities provided during the study period by the department of Food Science and Nutrition, CCAS, MPUAT, Udaipur.

\section{References}

Anhe, F. F., Desjardins, Y., Pilon, G., Dudonne, S., Genovese, M. I., Lajolo, F.M. and Marette, A. 2013. Polyphenols and Type 2 diabetes: A prospective review. Pharma Nutrition. 1: 105-114.

APHA (American Public Health Association) 1976. Compendium of Methods for the Microbiological Examination of Foods. M. L. Speck, editor. ed. Washington, D.C.: APHA.

Beniwal, P. and Jood, S. 2015. Development, Chemical Composition and Antioxidant Activity of Dosa Prepared Using Bengal Gram Seed Coat. International Journal of Advanced Nutritional and Health Science. 3(1): 109-115.

Berghofer, L.K., hocking, A.D., Miskelly, D., Jansson, E. 2003. Microbiology of wheat and flour milling in Australia. International Journal of Food Microbiology. 85: 137-49.

Health benefits of Red Rice. 2016. Cited from https://www.healthbenefitstimes.com/he alth-benefits-of-red-rice/ retrieved on 21.9.17.

ICMSF.1998. Microorganisms in Foods. Microbial Ecology of Food Commodities. Blackie Academic and Professional, London. 6: 313-346.

Kadam, M.L., Salve, R.V., Mehrajfatema, Z.M. and More, S.G. 2012. Development and Evaluation of Composite Flour for Missi roti Ichapatti. Journal of Food Processing and Technology.3:1.

Kaur, A., Kochhar, A. and Prasad, P. 2016. Nutritional Evaluation of Value Added Products Using Potato Flour. International Journal of Health Sciences and Research. 6(1): 466-472.

Kumar, R., Yadav, N., Gupta, A.K., Chaka, J., Pravin, K., Tripathi, U. and Srivastava, O.P. 2004. Protein enrichment by incorporation and dehydrated leafy vegetables. In proceedings of xxvii annual national convention, Indian Dietetic Association held at New Delhi during Oct 8-9: 101.

Lohekar, A.S. and Arya, A.B. 2014. 
Development of value added instant 'dhokla' mix. International Journal of Food and Nutritional Sciences. 3(4):7883.

Mohan V, Gokulakrishnan K, Sandeep S, Srivastava BK, Ravikumar R, Deepa R. 2006. Intimal media thickness, glucose intolerance and metabolic syndrome in Asian Indians, the Chennai urban rural epidemiology study. Diabetic Medicine. 23: 845-50.

Patangare, S.S. 2019. Development and quality evaluation of instant dhokla mix prepared from foxtail millet and horse gram. Btech in food technology, Thesis, Department of Food Technology, Vasantrao Naik Marathwada Krishividyapeeth, Parbhani.

Raghuram, T.C, Pasricha, S. and Sharma, R.D. 2010. Diet and diabetes. Published by NIN.

Roopa, S.S, Dwivedi, H. and Rana, G.K. 2017. Development and Physical, Nutritional and Sensory Evaluation of Instant Mix (DOSA). TECHNOFAMEA Journal of Multidisciplinary Advance Research. 6(1): 109-113.
Setamou, M., Cardwell, K.F., Schulthess, F. and Hell, K. 1997. Aspergillus flavus infection and aflatoxin contamination of pre-harvest maize in Benin. Plant Disease. 81: 1323-1327.

Singh, H.G. and Pathak, A. 2002. Effect of composite flours and additives on the texture of chapatti. Journal of Food Engineering. 55(2): 173-179.

Victor, N., Bekele, M.S. Ntseliseng, M., Makotoko, M., Peter, C. And Asita, A.O. 2013. Microbial and physicochemical characterization of maize and wheat flour from a milling company, Lesotho. Internet Journal of Food Safety. 15: 11-19.

Vij, S., and Subramanian, P. 1999. Laboratory manual in dairy and food microbiology. Department of dairy and food microbiology, RAU,1:1.

Visanthamein, G. and Savita, D. 2001. Hypoglycaemic and hypocholesterolemic effect of selected powder. Indian Journal of Nutrition and Diabetes 38: 419-27.

\section{How to cite this article:}

Krishna Mishra and Renu Mogra. 2020. Development of Red Rice based Low Glycaemic Flour and the Microbial Activity during Storage. Int.J.Curr.Microbiol.App.Sci. 9(07): 123-134.

doi: https://doi.org/10.20546/ijcmas.2020.907.014 